ROCZNIKI PEDAGOGICZNE

Tom 12(48), numer $2-2020$

DOI: http://dx.doi.org/10.18290/rped20122-8

ANNA BADORA

\title{
POTENCJAŁ CYBERPRZESTRZENI DLA ROZWOJU ZDOLNOŚCI DO TWÓRCZOŚCI OSOBY W OCENIE STUDENTÓW PEDAGOGIKI
}

\section{ZDOLNOŚĆ DO TWÓRCZOŚCI OSOBY}

W różnorodności żywych organizmów człowiek stanowi byt wyjątkowy. Osoba, czerpiąc z podobieństwa do własnego Stwórcy, została obdarowana szczególnymi przymiotami: godnością, rozumnością, wolnością, odpowiedzialnością, zdolnością do miłości, twórczości, transcendencji. Każdy z tych przymiotów definiuje osobę, jest przypisany tylko jej jako nierozerwalnie wpisany w człowieczeństwo.

J. Rudniański (1981, s. 15) pisze, że „Działanie twórcze w określonym wysokim stopniu jest jedną z podstawowych cech człowieka, która doprowadziła go do tego, czym jest, i wyróżnia go spośród innych ssaków”. Każdy człowiek z racji swojego człowieczeństwa posiada zdolność do twórczości. Podobnie twierdzi A. Cudowska (2004, s. 27): „Twórczość jest jedną w podstawowych cech człowieka i przynależy każdemu podmiotowi, chociaż urzeczywistnia się w różnym stopniu u poszczególnych jednostek". Zdolność do twórczości stanowi więc pewien zasób, który w różnym stopniu jest indywidualnie realizowany. W tym kontekście należy przyjąć, że twórczość nie przynależy tylko do wybitnych postaci, przeciwnie jest predyspozycją powszechną. Co więcej, to właśnie możliwość twórczości stanowi uniwersalny środek dla realizowania założonych celów.

Stanowiąc jeden $\mathrm{z}$ najistotniejszych aspektów człowieczeństwa, twórczość jest rzeczywistością wielowymiarową. K. Szmidt (2007, s. 62) wskazuje na czteroaspektowy paradygmat interpretacji twórczości:

Dr AnNA BADORA - Katedra Dydaktyki i Edukacji Szkolnej, Instytut Pedagogiki Katolickiego Uniwersytetu Lubelskiego Jana Pawła II, Lublin: e-mail: rudaanna89@gmail.com; ORCID: https://orcid.org/0000-0003-4027-6792 
„1) twórczość jako wytwór (aspekt atrybutywny)

2) proces psychiczny (aspekt precesualny)

3) osoba twórcy (aspekt personologiczny)

4) czynniki zewnętrzne warunkujące proces tworzenia (aspekt stymulatorów i inhibitorów)".

Każdy z przedstawionych wymiarów jest elementem koniecznym dla urzeczywistnienia zdolności do twórczości. Dodatkowo przedstawione wymiary nie stanowią odosobnionych rzeczywistości. Zależności pomiędzy nimi prezentuje poniższy schemat.

Schemat 1. Zależności między wymiarami twórczości

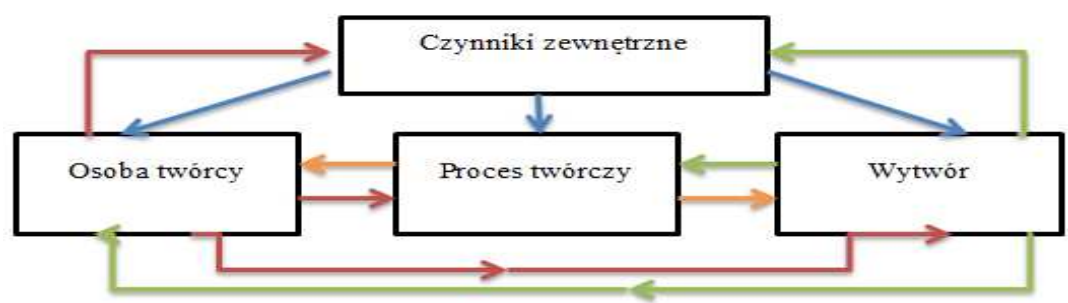

Źródło: opracowanie własne

Pierwszym czynnikiem istotnym dla zaistnienia twórczości jest osoba twórcy, która nie tylko uruchamia proces twórczy, ale także kształtuje czynniki zewnętrzne oraz przez własną indywidualność nadaje określony charakter wytworowi. Należy jednak podkreślić, że osoba twórcy, dysponując pewnymi doświadczeniami społecznymi, a także istniejąc $\mathrm{w}$ określonym kontekście społeczno-kulturowym, podlega oddziaływaniu czynników zewnętrznych, które mogą przyjmować charakter stymulujący bądź inhibitujący dla twórcy. R. Schulz (1990, s. 337) podkreśla, że „twórczość rozkwita bowiem (albo gaśnie), nie tylko pod wpływem obiektywnych sytuacji, w jakich żyje człowiek, ale także pod wpływem systemu wartości, który rozpowszechniony jest $\mathrm{w}$ społeczeństwie. [...] O ile warunki zmuszają niejako ludzi do manifestowania zachowań twórczych, o tyle system wartości sprawia, że ludzie chcą być twórczy; udział w aktywności twórczej staje się przedmiotem ich pragnień". Ponadto podjęty przez osobę proces twórczy także na nią oddziałuje. Psychologiczne składowe procesu twórczego są konieczne dla zaistnienia innych operacji myślowych. Jak podkreśla A. Góralski (2003, s. 45-52), „Akt bawienia się nie wymaga żadnych dodatkowych motywów, nagród ani uzasadnień. Nasuwa się więc wniosek, że zabawa to 
ewolucyjny wynalazek, dzięki któremu oddajemy się pewnym czynnościom, nie pytając o ich sens, przez co ćwiczymy ważne funkcje psychiczne i rozwijamy umysł. Należałoby w takim razie uznać, że twórczość jest dojrzałą formą zabawy". Także sam wytwór, kiedy już zaistnieje, wzbogaca swojego twórcę. Dostarcza mu nowej perspektywy postrzegania.

Powyższy schemat wskazuje, że jak w przypadku osoby twórcy, tak analogicznie zależności między poszczególnymi wymiarami twórczości przebiegają dwutorowo. Każdy $\mathrm{z}$ aspektów oddziałuje na pozostałe, jednocześnie sam podlegając oddziaływaniu. To właśnie te wzajemne zależności stanowią o znaczeniu i wadze urzeczywistnionej zdolności do tworzenia.

Zdolność do twórczości jest wpisana w naturę człowieka. Jednak sama twórczość nie odnosi się do działań w sferze natury, a jest powołana do przekształcania kultury. Akt odnoszący się do natury ma charakter „stwórczy” powołuje do życia, przez co jest on przypisany tylko Bogu. Twórczość człowieka zawsze dotyka kultury, jest osadzona w kulturze, stanowi swoistą kontynuację dzieła rozpoczętego, jednak czerpie z kontekstu naturalnego i kulturowo-społecznego. A. Góralski (2003) podkreśla, że szczególne znaczenie dla twórczości ludzkiej mają prawa naturalne, które mimo że same nie podlegają twórczości ludzkiej, stanowią czynnik regulujący dla całego procesu twórczego. Z kolei R. Schulz (1990, s. 330) wskazuje, że „Twórczość jest zjawiskiem społecznym, dlatego że pozostaje w genetycznych i funkcjonalnych powiązaniach z kulturą danej zbiorowości: wyrasta $\mathrm{z}$ określonych doświadczeń życia zbiorowego i prowadzi do nich z powrotem przez ich wzbogacanie o nowe elementy".

Zdolność do twórczości osoby stanowi swoisty pomost między obszarem natury i kultury. W twórczości człowieka te dwie płaszczyzny przenikają się, dostarczając sobie wzajemnie rozwiązań progresywnych. S. Popek (2015, s. 25) stoi na stanowisku, że „twórczość swoim zakresem obejmuje wszystko to, co nie jest pierwotnym dziełem przyrody, a zatem w skład twórczości wchodzą takie dziedziny, jak: sztuka, nauka, technika, organizacja życia społecznego i różnorodne czynności życia ludzkiego dnia codziennego". Zdolność do twórczości nie jest przypisana wyłącznie światu sztuki, jej urzeczywistnianie dokonuje się w każdej dziedzinie życia codziennego, w której człowiek staje przed koniecznością rozwiązania określonych problemów, poszukiwania nowych rozwiązań. Uniwersalność twórczości rozciąga się nie tylko na dziedziny, w których jest realizowana, ale także obejmuje samego człowieka, który tworząc, sam staje się „obrazem” twórczości. Jak podkreśla Z. Pietrasiński (1969, s. 127): „Działalność twórcza nie sprowadza 
się tylko do aktywności intelektualnej, ale absorbuje całą osobowość, wymaga często specjalnego ukształtowania całego życia jednostki”. Urzeczywistnienie zdolności do tworzenia zmienia nie tylko otaczającą rzeczywistość, ale także ubogaca osobę, która podjęła się tego urzeczywistnienia. Innymi słowy - tworząc, człowiek nie tylko kreuje coś nowego, ale także sam staje się kimś nowym przez doświadczenie: wszystkich czynników zewnętrznych towarzyszących procesowi twórczemu, samego procesu, a także wytworu, który jest jego efektem.

Podsumowując dotychczasowe analizy, należy podkreślić, że zdolność do twórczości:

- przynależy każdej osobie,

- posiada cztery wymiary niezbędne dla jej realizacji: osobę twórcy, proces twórczy, wytwór, czynniki zewnętrzne,

- między wymiarami zachodzą wzajemne dwukierunkowe zależności oddziaływania,

- urzeczywistniana jest we wszystkich przestrzeniach życia społeczno-kulturowego,

- urzeczywistniana - dotyka i zmienia także samego twórcę.

Dodatkowo, jak podkreśla N. Lazarewicz (2011, s. 62): „Twórczość stanowi atrybut działalności ludzkiej, jej ważniejszą nieodłączną właściwość, która zdeterminowała zaistnienie człowieka i cywilizacji ludzkiej oraz leży u podstaw dalszego postępu kultury materialnej i duchowej”.

\section{CYBERPRZESTRZEŃ A ZDOLNOŚĆ DO TWÓRCZOŚCI OSOBY}

Nieustannie dokonujący się rozwój technologiczny spowodował, że współczesny człowiek zaczął podejmować działania także w przestrzeni internetu. Kategoria cyberprzestrzeni zaistniała jako odpowiedź na wszystkie procesy, relacje, aktywności dokonujące się w rzeczywistości sieciowej. J. Bednarek (2014, s. 24) podkreśla, że cyberprzestrzeń „Jest to nowy rodzaj przestrzeni wspierany przez nowe technologie, a komunikacja zachodząca w jej obrębie znajduje się w fazie wzrostu i rozwoju, także silnych transformacji. Możemy w niej funkcjonować na zasadzie przestrzeni społecznej jakby zastępując kawiarnie czy parki, gdzie ludzie spotykają się w codziennych interakcjach. Ponadto w cyberprzestrzeni można kreować sytuacje, co powoduje uczucie „współdzielenia” przestrzeni z drugą osobą, która również pozostaje w trybie online w tym samym czasie". Kolejne pokolenia coraz 
sprawniej funkcjonują w cyberprzestrzeni, nierzadko kosztem ,prawdziwego życia”. K. Tomisia (2008, s. 141) stoi na stanowisku, że „W kontekście wzrostu znaczenia mediów elektronicznych na życie współczesnego człowieka mówi się o dwóch procesach: mediatyzacji, tj. przenoszenia coraz większej liczby doświadczeń z życia realnego w przestrzeń wirtualną, oraz technopolizacji, czyli wzroście liczby i różnorodności dostępnych informacji, a także rozmaitości kanałów, jakimi są one dostarczane". Zaangażowanie, szczególnie młodzieży, w działalność sieciową jest na tyle wysokie, że cyberprzestrzeń staje się dla nich drugą naturalną płaszczyzną działania. W tym kontekście istotne staje się zwrócenie uwagi na zagrożenia, z którymi spotykają się użytkownicy sieci. A. Roguska (2012, s. 208) wskazuje, że „W relatywizmie kulturowym zwłaszcza młodzież nie może odnaleźć własnej tożsamości ani systemu wartości. Obecnie zgodnie z rzeczywistością ukazywaną w mediach młodzi ludzie starają się żyć modnie. Funkcjonują według zasady 'tu i teraz'. Ich system wartości jest zmienny. W zależności od sytuacji wartość staje się przywarą, a przywara - wartością". Spectrum niebezpieczeństw, które są obecne w sieci, jest bardzo szerokie, źródłem większości jest poczucie zagubienia i niezrozumienia dostępnych wartości. Jednak koncentracja wyłącznie na aspektach trudnych wydaje się być zbyt jednostronna. Konieczne staje się poszukiwanie elementów cyberprzestrzeni, które mogłyby realnie przyczyniać się do integralnego rozwoju osoby. W przedstawionym artykule podjęto próbę analizy możliwości sieci dla rozwoju zdolności do twórczości.

Jak już nadmieniono, zdolność do twórczości przynależy każdej osobie i jest możliwa do urzeczywistniania we wszystkich dziedzinach życia społeczno-kulturowego. Te dwa istotne elementy zdolności do twórczości stanowią jej podstawę i wzajemnie się uzupełniają. Jednak nie zawsze są w pełni akceptowane i dostrzegane przez osobę. Wraz z upływem kolejnych doświadczeń społecznych $\mathrm{w}$ wychowankach budowane jest przeświadczenie o przynależności twórczości wyłącznie artystom, osobom wybitnie zdolnym w określonej dziedzinie sztuki. Jak zaznacza L. Stanisławowski (2013, s. 132), „Wrażliwość na wartości piękna rozbudzana jest w szkole najskuteczniej podczas edukacji wczesnoszkolnej. W gimnazjum, niestety duża grupa młodzieży przechodzi kryzys w swobodnej twórczości plastycznej. [...] Młodzież spotyka się z pięknem, wielokrotnie posiada potrzebę obcowania z nim, lecz nie potrafi go kreować w swoich kompozycjach plastycznych. Jest tym mocno zaniepokojona i zniechęcona do dalszej pracy". Autor, odnosząc się do twórczości plastycznej wychowanków, wskazuje, że wraz 
z wiekiem dzieci wzrasta ich zniechęcenie do podejmowania tej aktywności. Młodzieńczy „kryzys twórczy” odnosi się do większości realizowanych działań i eskaluje, kiedy próby działań twórczych są piętnowane przez otoczenie i postrzegane przez nie jako coś niepotrzebnego, zbyt odbiegającego od przyjętych założeń.

Zupełnie inną perspektywę oferuje cyberprzestrzeń. Szczególną jej właściwością jest „demokratyczność”. Uzyskując dostęp do internetu osoba staje się pełnoprawnym członkiem społeczności sieci. B. Szmigielska (2009, s. 15) zwraca uwagę, że „Każdy, kto przebywając w wirtualnej przestrzeni, korzysta $\mathrm{z}$ informacji tam istniejących, zamieszcza swoje informacje, oraz uczestniczy w relacjach społeczności wirtualnej (zarówno biernie jak i aktywnie) występuje w podobnej roli: edukatora i edukowanego jednocześnie". Sieć internetowa zapewnia swoim użytkownikom prawo do oceny ich działań i wytworów tylko z perspektywy uzyskanych efektów. Innymi słowy nie ma znaczenia stopień zaawansowania, doświadczenie, wiek czy pochodzenie osoby, ostatecznym kryterium weryfikacji jest sam wytwór. W tym kontekście każdy z użytkowników sieci jest potencjalnym twórcą. Natomiast podejmowaniu działań twórczych sprzyja dodatkowo poczucie anonimowości. W. Sowa (2008, s. 161) zaznacza: „względna anonimowość użytkowników internetu pozwala na większą samodzielność jednostki i w dużym stopniu ogranicza zewnętrzna kontrolę jej działań. [...] Używanie internetu w procesie przyswajania wiedzy szkolnej przez uczniów szkół średnich i studentów pochodzących z różnych kręgów kulturowych zwiększa poczucie niezależności działania i brania odpowiedzialności za swoja edukację”. Świadomość anonimowości motywuje do podejmowaniu „twórczego ryzyka”, zapewnia poczucie bezpieczeństwa, w którym, w razie niepowodzenia, osoba nie jest utożsamiana z wytworem.

Kompilacja demokratyczności i anonimowości, którą oferuje cyberprzestrzeń, utwierdza w jej użytkownikach przeświadczenie o posiadaniu zdolności do tworzenia, a przez to do urzeczywistniania twórczości.

Rozpowszechnienie dostępu do zasobów cyberprzestrzeni spowodowało, że szerokie grono odbiorców ma możliwość poznawania zupełnie nowych obszarów działalności. B. Maj (2007, s. 29 ) zaznacza, że „Niepowtarzalną zaletą internetu jest łatwy i natychmiastowy dostęp do najróżniejszych danych, kolejną zaś ich aktualność: żadna inna forma gromadzenia wiedzy nie może się w tym względzie równać z elektroniczną”. Z kolei J. Gajda (2007, s. 147) podkreśla, że „Cyberprzestrzeń daje szansę każdemu, kto w niej istnieje i kto chce ustanowić kilka połączeń, aby rozpowszechniać informacje 
- stąd stwarza okazję do zaistnienia inności i odmienności, dzięki czemu zyskują peryferia”. Cyberprzestrzeń przez swoją dostępność, a także szybkość przekazu dowodzi swoim użytkownikom, że działania twórcze mogą być realizowane w każdej dziedzinie życia. Doskonałym przykładem tego oddziaływania jest serwis YouTube. Jak wskazuje W. Otto (2009, s. 269): „YouTube stał się prawdziwą kopalnią amatorskich filmów oraz rozmaitych krótkich form filmowych i telewizyjnych. [...] Krótkie formy filmowe szorty - gatunkowo bardzo różne, a tematycznie wręcz nieograniczone, o niezwykle zróżnicowanym poziomie artystycznym, od niedawna stanowią nieodzowny element kultury filmowej internetu". Ponadto dostępność sieci stanowi szczególne wyzwanie dla twórców. Chcąc zaistnieć, w ogromie treści i obrazów, muszą dodatkowo tworzyć coraz nowe obszary dla własnej działalności o szczególnej oryginalności. W tym kontekście cyberprzestrzeń staje się potwierdzeniem dla założenia zdolności do twórczości, że może być ona realizowana w każdej dziedzinie życia.

Znacznej modyfikacji podlegają w cyberprzestrzeni relacje między poszczególnymi aspektami działalności twórczej, ich dwutorowość zostaje zachowana, natomiast zmianie ulega ich specyfika. Zwłaszcza zależność oddziaływania między twórcą i czynnikami zewnętrznymi. A. Lekka-Kowalik (2005, za: Andrzejewska, 2009, s. 165) podkreśla: „Wszyscy internauci tworzą cyberspołeczeństwo. Posiada ono swój informacyjno-informatyczny charakter za sprawą internetu, który stał się bardzo skutecznym narzędziem szybkiego przekazywania wiadomości i informacji oraz kanałem komunikacji. Ważną rolę odgrywa tam 'bliskość' ludzi znajdujących się na łączach tak, że możemy mówić o nowym wymiarze społeczeństwa”. Cyberspołeczeństwo, które przyjmuje rolę czynników zewnętrznych dla twórczości, charakteryzuje bezpośredniość w wyrażaniu ocen oraz formułowaniu opinii. Akceptacja dla wytworu jest bardzo entuzjastyczna i wyraża się w udostępnianiu go kolejnym użytkownikom. Proces rozpowszechniania przebiega bardzo szybko, dzięki czemu twórca otrzymuje właściwie natychmiastową odpowiedź na popełniony wytwór.

Zmianie ulega także specyfika relacji pomiędzy twórcą a samym wytworem. Jak podkreśla J. Kandzia (2015, s. 67): „Świat wirtualny to świat pod kloszem, dający komfort eksperymentowania. [...] Internet zmusza do rezygnacji z modelu nauczania pamięciowego na rzecz takiego, w którym prym wiedzie myślenie [...]". Przestrzeń internetu stanowi swoisty bufor dla podejmowanych działań twórczych. Decydując się na ich realizację w określo- 
nej dziedzinie, osoba otrzymuje zabezpieczenie, że jej aktywność, dokonując się w sieci, pozostaje w niej aż do osiągnięcia zadowalającego kształtu.

Przedstawiona analiza stanowi zaledwie wstęp dla dalszych poszukiwań możliwości cyberprzestrzeni dla urzeczywistniania zdolności do twórczości osoby. Należy także podkreślić, że wyszczególnione potencjały wykorzystywane w sposób nieodpowiedzialny, w imię źle pojmowanej wolności, mogą przekształcać się w zagrożenia dla integralnego rozwoju osoby.

\section{POTENCJAŁ CYBERPRZESTRZENI DLA ZDOLNOŚCI DO TWÓRCZOŚCI OSOBY W OCENIE STUDENTÓW PEDAGOGIKI}

Dla realizacji wyznaczonego celu przeprowadzono badania o charakterze jakościowym, za pomocą techniki analizy treści swobodnych wypowiedzi. W badaniach uczestniczyło 42 studentów pedagogiki Katolickiego Uniwersytetu Lubelskiego Jana Pawła II. Temat swobodnej wypowiedzi sformułowano następująco: „Możliwości cyberprzestrzeni dla rozwijania zdolności do twórczości osoby".

W uzyskanych swobodnych wypowiedziach studentów zauważono pewne punkty wspólne. Umożliwiły one sklasyfikowanie zebranego materiału w dwie główne grupy: w pierwszej studenci wskazywali na możliwości inspiracji zawarte w sieci, w drugiej na znaczenie globalności cyberprzestrzeni.

Pierwsza grupa studentów w swoich swobodnych wypowiedziach akcentowała, że w ich ocenie cyberprzestrzeń stanowi przede wszystkim źródło inspiracji. Badani zwracali uwagę na zasoby sieciowe, które mogę stanowić czynnik motywujący dla realizacji twórczości. Jedna ze studentek w następujący sposób sformułowała swoją wypowiedź:

Spędzamy dużo czasu w sieci. Prawie cały czas jesteśmy dostępni. Nawet w wolnym czasie przeglądamy FB lub Instagram. I w sumie już przy takim przeglądaniu można się czymś zainspirować. Mam wśród znajomych osoby, które mają ciekawe pasje i kiedy tak przeglądam ich zdjęcia, sama też planuję swoje aktywności. Może nie takie ekstremalne i bardziej związane z moimi zainteresowaniami, ale przez to, że oni coś robią, ja też chcę działać.

Badana w swojej wypowiedzi podkreśla, jak istotnym elementem rzeczywistości młodych ludzi jest cyberprzestrzeń. W jej ocenie sieć internetowa jest środowiskiem, w którym dzielenie się pewnymi aktywnościami staje się motywatorem do podjęcia własnych działań. Dodatkowo wskazuje, że nawet 
bierne zapoznawanie się z tym, w czym realizują inni, wywołuje poczucie konieczności podjęcia własnej działalności.

Z kolei inny student napisał:

Internet w dzisiejszych czasach jest ogromną bazą informacji. Portale internetowe oraz różnego rodzaju aplikacje umożliwiają nam rozwój zainteresowań oraz zdolności twórczych. Przeglądając codziennie internet, widzimy dużo różnych zdjęć, obrazów, słyszymy wiele różnych dźwięków, które mogą być wzorem i inspiracją naszych wytworów.

Powyższa wypowiedź wskazuje, że badany dostrzega szczególny potencjał cyberprzestrzeni dla twórczości w jej ogromnych zasobach. Różnorodność nie tylko treści, ale także środków wyrazu jest bardzo duża. Determinuje ona właściwie każdego użytkownika sieci na odnalezienie dla siebie zupełnie indywidualnej inspiracji do twórczości.

Studenci w swoich wypowiedziach wskazywali także nie tylko na zasoby środków, ale również zasoby personalne.

Kolejny z badanych twierdzi:

Możliwości cyberprzestrzeni dla zdolności do twórczości są zawarte w ludziach. To ludzie tworzą sieć internetową i są dla siebie nawzajem największą inspiracją.

Autor wypowiedzi zwraca uwagę, że cyberprzestrzeń nie jest zupełnie nowym światem, w którym procesami koordynuje maszyna. Badany podkreśla, że twórcami sieci są osoby. Personalny charakter przestrzeni internetu umożliwia wzbudzanie w jej użytkownikach potrzeby tworzenia.

Kolejna studentka pisze:

Kiedy udostępniam coś w internecie, każdy może to ocenić. Jest to dla mnie ważne, ponieważ od razu wiem, co powinnam zmienić, jak to ulepszyć. Dzięki temu rozwijam swoje umiejętności i twórczość. Chociaż czasem te oceny są bardzo hejtujące.

Badana zaznacza, że elementem ważnym przy realizacji twórczości dla twórcy staje się ocena innych. W cyberprzestrzeni dokonuje się ona natychmiastowo, przez co dynamizuje cały proces tworzenia.

$\mathrm{Na}$ nieco inny aspekt zwraca uwagę kolejna badana:

W cyberprzestrzeni można porozmawiać z każdym. Jeżeli coś zaciekawi mnie w pracach artysty mogę do niego napisać i wiem, że on mi odpisze. Myślę, że to jest ważne dla twórczości, że mogę nawiązać kontakt z naprawdę wielkimi osobami. 
Podobnie pisze inna studentka:

\begin{abstract}
Za pomocą Twittera czy live na Insta mogę porozmawiać z moimi idolami. Mogę też skonsultować pewne rzeczy ze specjalistami, uzyskać od nich opinię na temat tego, co robię, czy według nich jest to wartościowe.
\end{abstract}

Analiza przedstawionych wypowiedzi umożliwia sformułowanie wniosku, że czynnikiem sprzyjającym urzeczywistnianiu zdolności do twórczości, który zawiera sieć internetowa, jest swobodna komunikacja między wszystkimi użytkownikami sieci. Interesariusz może nawiązać rozmowę ze słynnym twórcą, przez co nie tylko czerpie inspirację dla własnych działań, ale także może konsultować swoje dokonania, a przez to je ulepszać. Cyberprzestrzeń stwarza warunki do płynnej i zrównoważonej wymiany doświadczeń.

W drugiej grupie sklasyfikowano wypowiedzi, które nawiązywały do globalnego charakteru cyberprzestrzeni.

$\mathrm{W}$ jednej z wypowiedzi napisano:

Internet może być ważny dla twórczości, ponieważ jest ogólnodostępny. Każdy może tam wrzucać to, na co tylko ma ochotę. Jeżeli rysujesz, możesz te rysunki zostawić w internecie, jeżeli są dobre, to na pewno ktoś się tobą zainteresuje, a jeśli są przeciętne, to po prostu zostaną niezauważone. Ale zawsze możesz próbować do skutku.

Badany podkreśla, że tym, co stanowi potencjał dla zdolności do twórczości, jest swoiste równouprawnienie w procesie udostępniania wytworów. Każdy z użytkowników sieci ma prawo umieszczać w niej to, czym chciałby podzielić się z pozostałymi cybertubylcami.

Inna studentka napisała:

Zdolność do twórczości będzie rozwijała się wtedy, gdy ktoś będzie na nią reagował. Internet ma tak duży zasięg, że wrzucając coś do niego, zwiększamy szanse na to, że nasza twórczość będzie zauważona. Poza tym przez cyberprzestrzeń możemy też ze swoją twórczością wychodzić za granicę.

Wypowiedź badanej umożliwia sformułowanie wniosku, że potrzeba akceptacji i aprobaty wytworu jest czynnikiem sprzyjającym realizacji twórczości. Cyberprzestrzeń, oferując połączenia globalne, zwiększa możliwości dostrzeżenia działania przez społeczność, co z kolei determinuje kolejne aktywności. 


\section{PODSUMOWANIE}

W powyższym artykule podjęto próbę określenia, w czym wyraża się potencjał sieci internetowej dla rozwijania zdolności do twórczości osoby. Analiza teoretyczna literatury i empiryczna wypowiedzi studentów umożliwiła określenie punktów cyberprzestrzeni o charakterze progresywnym dla zdolności do twórczości, w formie skróconej przedstawiono je w poniższej tabeli.

Tabela nr 1. Punkty progresywne w cyberprzestrzeni dla twórczości

\begin{tabular}{|l|l|}
\hline \multicolumn{1}{|c|}{$\begin{array}{c}\text { Wynikające } \\
\text { z analizy literatury }\end{array}$} & \multicolumn{1}{c|}{$\begin{array}{c}\text { Wynikające } \mathbf{z} \text { analizy } \\
\text { wypowiedzi studentów }\end{array}$} \\
\hline Demokratyczność sieci & Szeroki zasób treści i środków jako inspiracji \\
\hline Anonimowość użytkowników & Szerokie zasoby personalne \\
\hline $\begin{array}{l}\text { Silna współzależność twórcy i czynników ze- } \\
\text { wnętrznych (sieciowych) }\end{array}$ & Dostępność i płynność komunikacji \\
\hline Możliwość ciągłej modyfikacji wytworu & Natychmiastowa ocena \\
\hline & Równouprawnienie w procesie udostępniania \\
\hline & Globalny zasięg \\
\hline
\end{tabular}

Źródło: Opracowanie własne

Należy jednak podkreślić, że przedstawiony artykuł stanowi jedynie wstępny zarys zagadnienia, które wymaga bardziej zaawansowanych analiz, umożliwiających określenie konkretnych rozwiązań edukacyjnych.

\section{BIBLIOGRAFIA}

ANDRZEJEwSKA, A. (2009). Świat wirtualny kreatorem rzeczywistości dziecka. W: J. BedNAREK, A. ANDRZEJEwSKA (red.), Cyberświat możliwości i zagrożenia. Warszawa: Żak.

BEDNAREK, J. (2014). Społeczne kompetencje medialno-informacyjne w kontekście bezpieczeństwa w cyberprzestrzeni i świata wirtualnego. W: J. BEDNAREK (red.), Człowiek w obliczu szans cyberprzestrzeni i świata wirtualnego. Warszawa: Difin.

CudowsKa, A. (2004). Ksztattowanie twórczych orientacji życiowych w procesie edukacji. Białystok: Stowarzyszenie Trans-Humana.

GajdA, J. (2007). Media w edukacji. Kraków: Wyższa Szkoła Pedagogiczna ZNP.

GóRALSKI, A. (2003). Teoria twórczości. Eseje filozoficzne i pedagogiczne. Warszawa: Akademia Pedagogiki Specjalnej. 
KANDZIA, J. (2015). Innowacyjne postawy podmiotów procesu kształcenia matematycznego w cyberprzestrzeni. W: Bednarek, A. Andrzejewska (red.), Cyberprzestrzeń, człowiek, edukacja. Dylematy społeczności cyfrowej. Karków: Impuls.

LAZAREWICZ, N. (2011). Twórczość jako jedność możliwego i koniecznego. W: J. ŁASZCZYK (red.), Filozofia i pedagogika twórczości - główne problemy, zasadnicze rozstrzygnięcia. Warszawa: Uniwersitas Rediviva.

MAJ, B. (2007). Internet jako medium edukacyjne - szanse oraz zagrożenia. W: M. SoKOŁOWSKI (red.), Oblicza internetu. Architektura komunikacyjna sieci. Elbląg: Opus.

OтTо, W. (2009). Krótkie formy filmowe w internecie. W: M. JEZIŃSKI (red.), Nowe media a media tradycyjne. Toruń: Adam Marszałek.

PIETRAsińsKI, Z. (1969). Myślenie twórcze. Warszawa: Państwowe Zakłady Wydawnictw Szkolnych.

POPEK, S. (2015). W kręgu aktywności twórczej. Lublin: Wydawnictwo UMCS.

Roguska, A. (2012). Media globalne - media lokalne. Zagadnienia z obszaru pedagogiki medialnej i edukacji regionalnej. Kraków: Impuls.

RUDNIAŃSKI, J. (1981). Homo cogitans. O myśleniu twórczym i kryteriach wartości. Warszawa: Wiedza Powszechna.

Schulz, R. (1990). Twórczość spoteczne aspekty zjawiska. Warszawa: Państwowe Wydawnictwo Naukowe.

SowA, W. (2008). Rola internetu w podejmowaniu decyzji edukacyjno-zawodowych w ocenie maturzystów. W: B. Szmigielska (red.), Całe życie w sieci. Kraków: Wydawnictwo UJ.

STANISŁAwowsKi, L. (2013). Reakcja na piękno wśród młodzieży gimnazjalnej. W: A. ŻuKowsKA (red.), Edukacyjny i terapeutyczny aspekt sztuki. Lublin: Wydawnictwo UMCS.

SzMidT, K. (2007). Pedagogika twórczości. Gdańsk: Wydawnictwo Psychologiczne.

SzMigielska, B. (2009). Internet jako środowisko edukacyjne. W: B. SzMigielsKa (red.), Psychologiczne konteksty internetu. Kraków: Wydawnictwo WAM.

ToMisiA, K. (2008). Edukacja moralna młodzieży w przestrzeni internetu. W: B. SzMIGIELSKA (red.), Całe życie w sieci. Kraków: Wydawnictwo UJ.

\section{POTENCJAŁ CYBERPRZESTRZENI DLA ROZWOJU ZDOLNOŚCI DO TWÓRCZOŚCI OSOBY W OCENIE STUDENTÓW PEDAGOGIKI}

\section{STRESZCZENIE}

Celem przedstawionego artykułu jest określenie punktów potencjału cyberprzestrzeni o charakterze progresywnym dla rozwoju zdolności do twórczości osoby w ocenie studentów pedagogiki. Przyjęty cel konstytuuje podział niniejszego artykułu na trzy podrozdziały. W pierwszym wyjaśnieniu poddano termin „,zdolność do twórczości osoby”. Cześć druga zawiera analizę teoretyczną, dotyczącą cyberprzestrzeni jako swoistego potencjału dla rozwijania zdolności do twórczości. Z kolei w ostatnim podrozdziale zawarto interpretację danych uzyskanych ze swobodnych wypowiedzi studentów pedagogiki, dotyczących poruszanego problemu.

Słowa kluczowe: cyberprzestrzeń; zdolność do twórczości. 


\section{THE POTENTIAL OF CYBERSPACE FOR THE DEVELOPMENT OF THE PERSON'S ABILITY TO CREATE IN THE ASSESSMENT OF PEDAGOGY STUDENTS}

\section{SUMMARY}

The purpose of the presented article is to determine progressive cyberspace potential points for the development of a person's creativity, in the opinion of pedagogy students.

The adopted goal constitutes the division of this article into three subsections. The first explanation deals with the term creativity of a person. Part two contains the theoretical analysis of cyberspace as a kind of potential for developing creativity. In the last section, the interpretation of data obtained from the free statements of pedagogy students regarding the problem is included.

Key words: cyberspaces; ability to creative. 